\title{
Evaluation and Testing of IONSIV IE-911 for the Removal of Cesium-137 from INEEL Tank Waste and Dissolved Calcines
}

\author{
N. R. Mann \\ T. A. Todd \\ K. N. Brewer \\ D. J. Wood \\ T. J. Tranter \\ P. A. Tullock
}

Published April 1999

Idaho National Engineering and Environmental Laboratory High Level Waste Program

Lockheed Martin Idaho Technologies Company Idaho Falls, Idaho 83415

Prepared for the

U.S. Department of Energy Assistant Secretary for Environmental Management Under DOE Idaho Operations Office

Contract DE-AC07-94ID13223 


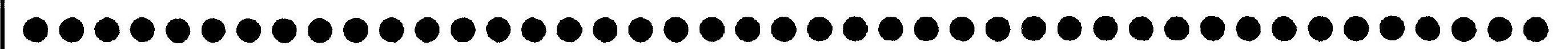




\section{DISCLAIMER}

This report was prepared as an account of work sponsored by an agency of the United States Government. Neither the United States Government nor any agency thereof, nor any of their employees, make any warranty, express or implied, or assumes any legal liability or responsibility for the accuracy, completeness, or usefulness of any information, apparatus, product, or process disclosed, or represents that its use would not infringe privately owned rights. Reference herein to any specific commercial product, process, or service by trade name, trademark, manufacturer, or otherwise does not necessarily constitute or imply its endorsement, recommendation, or favoring by the United States Government or any agency thereof. The views and opinions of authors expressed herein do not necessarily state or reflect those of the United States Government or any agency thereof. 


\section{DISCLAIMER}

Portions of this document may be illegible in electronic image products. Images are produced from the best available original document. 


\begin{abstract}
Development of waste treatment processes for the remediation of radioactive wastes is currently underway. A number of experiments was performed at the Idaho Nuclear Technology and Environmental Center (INTEC) located at the Idaho National Engineering and Environmental Laboratory (INEEL) with the commercially available sorbent material, IONSIV IE-911, crystalline silicotitanate (CST), manufactured by UOP LLC. The purpose of this work was to evaluate the removal efficiency, sorbent capacity and selectivity of CST for removing ${ }^{137} \mathrm{Cs}$ from actual and simulated acidic tank waste in addition to dissolved pilot-plant calcine solutions. The scope of this work included batch contact tests performed with non-radioactive dissolved Al and Run-64 pilot-plant calcines in addition to simulants representing the average composition of tank waste. Smallscale column tests were performed with actual tank WM-183 waste, tank waste simulant, dissolved Al and Run-64 pilot plant calcine solutions.
\end{abstract}

Batch contact experiments using simulated WM-183 tank waste with volume to mass ratios of approximately 25 and 100 displayed $K_{d}$ values of 1225 and 1120 , respectively. Batch contact experiments using dissolved Al pilot-plant calcine with volume to mass ratios of approximately 25 and 100 displayed $K_{d}$ values of 1623 and 1487, respectively. Batch contact experiments using dissolved Run-64 pilot-plant calcine with volume to mass ratios of approximately 25 and 100 displayed $K_{d}$ values of 4926 and 3694 , respectively.

Small-scale column experiments using actual WM-183 tank waste resulted in fiftypercent ${ }^{137} \mathrm{Cs}$ breakthrough at approximately 589 bed volumes. Small-scale column experiments using the tank waste simulant displayed fifty-percent ${ }^{137} \mathrm{Cs}$ breakthrough at approximately 700 bed volumes. Small-scale column experiments using dissolved Al calcine simulant displayed fifty-percent ${ }^{137} \mathrm{Cs}$ breakthrough at approximately 795 bed volumes. Column experiments with dissolved Run-64, pilot plant calcine did not reach fifty-percent breakthrough throughout the test. 
0
0
0
0
0
0
0
0
0
0
0
0
0
0
0
0
0
0
0
0
0
0
0
0
0
0
0
0
0
0
0
0
0
0
0 


\section{ACKNOWLEDGMENTS}

The authors would like to express their appreciation to UOP LLC for providing samples of IONSIV IE-911 for testing. The authors would also like to thank Jeff Laug, Duane Lundholm and Dennis Nielsen of the Spectrochemical Analysis Group. In addition, Chris Ortel, Lee Hinckley and Stacey Hill of the Radiochemical Analysis Group for their quick and expedient sample analysis. 


\section{CONTENTS}

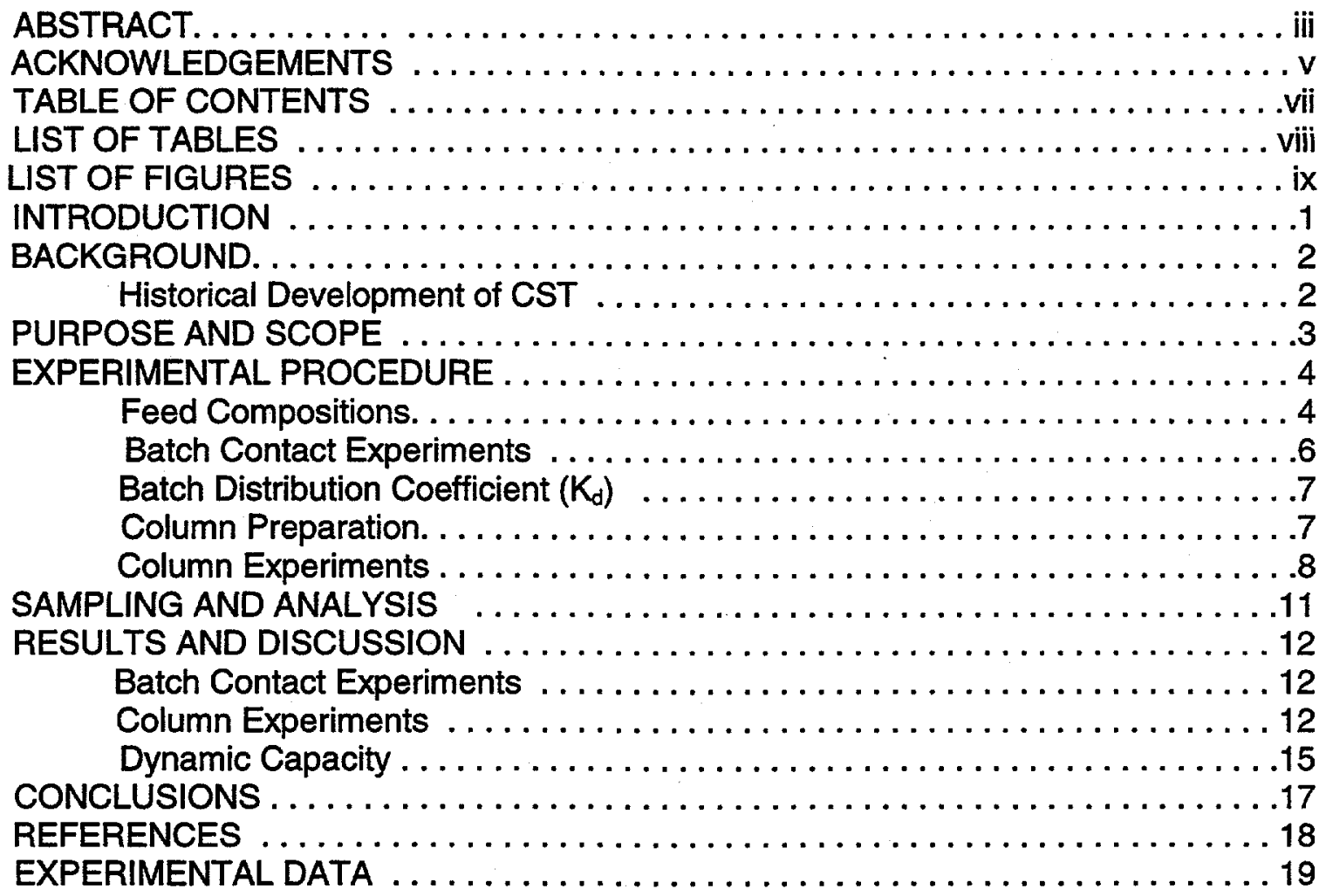




\section{LIST OF TABLES}

Table 1. Dissolved Al and Run-64 pilot-plant calcine feed compositions . . . . . . . 4

Table 2. Actual tank WM-183 waste, WM-183 simulant and average tank waste simulant compositions . . . . . . . . . . . . . . . . . 5

Table 3. Batch contact experimental conditions $\ldots \ldots \ldots \ldots \ldots \ldots \ldots$

Table 4. Properties of the IONSIV IE-911 column experiments $\ldots \ldots \ldots \ldots \ldots$

Table 5. Batch contact experimental conditions and results $\ldots \ldots \ldots \ldots \ldots \ldots 12$

Table 6. Dynamic capacities for small-scale column experiments . . . . . . . . . 16 


\section{LIST OF FIGURES}

Figure 1. Process schematic of assembled ion-exchange process $\ldots \ldots \ldots \ldots \ldots$

Figure 2. Ion exchange set-up installed in the Remote Analytical Laboratory . . . . . . 10

Figure 3. ${ }^{137} \mathrm{Cs}, \mathrm{Al}, \mathrm{Na}$, and $\mathrm{Sr}$ breakthrough curves for dissolved $\mathrm{Al}$ calcine simulant .13

Figure 4. ${ }^{137} \mathrm{Cs}, \mathrm{Ca}, \mathrm{Na}, \mathrm{Sr}$ and $\mathrm{K}$ breakthrough curves for dissolved Run-64 pilot-plant calcine simulant . . . . . . . . . . . . . . . . . . . . . . . . 14

Figure 5. Cesium-137 breakthrough curves for actual WM-183 tank waste and average

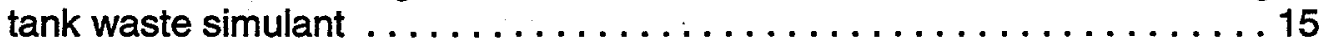




\section{Evaluation and Testing of IONSIV IE-911 for the Removal of Cesium-137 from INEEL Tank Waste and Dissolved Calcines}

\section{INTRODUCTION}

Development of waste treatment processes for the remediation of radioactive waste is currently underway at the Idaho Nuclear Technology and Engineering Center (INTEC) located at the Idaho National Engineering and Environmental Laboratory (INEEL). INTEC, formerly known as the Idaho Chemical Processing Plant (ICPP), previously reprocessed nuclear fuel to retrieve fissionable uranium. Approximately 5000 $\mathrm{m}^{3}$ of radioactive liquid waste remains, and is being stored in underground concrete encased stainless steel tanks. This waste is acidic with significant concentrations of sodium and potassium, but the specific composition of the waste varies from tank to tank. The ICPP historically solidified tank waste by calcining in a fluidized bed operated at $500^{\circ} \mathrm{C}$. Approximately $4,000 \mathrm{~m}^{3}$ of calcine are presently stored in concrete encased stainless steel bins at the INTEC. ${ }^{1}$

Radionuclide separation technologies are being evaluated for treating the tank waste and calcine. The purpose of this work was to evaluate IONSIV IE-911 for removing ${ }^{137} \mathrm{Cs}$ from acidic tank waste and dissolved pilot-plant calcine solutions. Batch contact tests were performed with non-radioactive dissolved Al and Run-64 pilot-plant calcines in addition to a simulant representing the average composition of tank waste. Small-scale column experiments were performed with actual tank WM-183 waste, tank waste simulant and dissolved Al and Run-64 pilot plant calcine simulants. 


\section{BACKGROUND}

\section{HISTORICAL DEVELOPMENT OF CST}

The development of waste treatment processes for the remediation of radioactive wastes has led to the development of several ion-exchange technologies, including crystalline silicotitanates (CST's). Beginning about 1980, researchers from Sandia National Laboratories and Texas A\&M University jointly discovered CST as the result of continued amorphous hydrous titanium oxide (HTO), development activities.

Initial experiments performed with the novel development materials, exhibited a high affinity for $\mathrm{Cs}, \mathrm{Sr}$ and several other radionuclides from highly alkaline solutions $(\mathrm{pH}>14)$ containing high $\mathrm{Na}^{+}$concentrations. In addition, the original development material showed excellent chemical and radiation stability. Together, the high selectivity and stability of CST's made them excellent candidates for treatment of radwaste solutions present at DOE facilities. ${ }^{2}$

A Sandia Laboratory Directed Research and Development (LDRD) project, in cooperation with Texas A\&M, soon followed and CST's were developed for radwaste applications. Sandia National Laboratory and UOP teamed under a Cooperative Research and Development Agreement (CRADA) to develop CSTs in a powdered form and an engineered form suitable for column ion exchange use. UOP has developed this material into commercial products: IONSIV IE-910 (CST powder) and IONSIV IE-911 (engineered form) respectively. ${ }^{3}$

Small-scale laboratory experiments have been performed at various DOE facilities such as Idaho, Hanford, Savannah River and Oak Ridge. ${ }^{4}$ Recent column experiments performed at Oak Ridge National Laboratory with actual Melton Valley Storage Tank (MVST) W-27 waste, with an adjusted pH of 13.3, displayed $50 \%$ breakthrough at approximately $350 \mathrm{CV}$. Flowrates of both 3 and $6 \mathrm{CV} / \mathrm{hr}$ were used. ${ }^{5}$ 


\section{PURPOSE AND SCOPE}

The purpose of this study was to evaluate the removal of ${ }^{137} \mathrm{Cs}$ from acidic INEEL tank waste and dissolved pilot-plant calcine solutions using IONSIV IE-911 (CST). This study was completed by performing small-scale batch contact experiments in addition to small-scale dynamic column experiments.

Batch contact tests were performed with non-radioactive dissolved $\mathrm{Al}$ and Run64 pilot-plant, calcine simulants in addition to a simulant representing the average composition of all tank waste. Small-scale column tests were performed with actual tank WM-183 waste, tank waste simulant and dissolved Al and Run-64 pilot plant calcine simulants. 


\section{EXPERIMENTAL PROCEDURE}

\section{FEED COMPOSITIONS}

Three tank waste feed solutions were used in these experiments, actual tank WM-183 waste, WM-183 simulant and an average composition simulant. The average simulant was prepared to have an average composition of all tank wastes stored at the INTEC.

Two forms of dissolved calcine were utilized for testing, Al and Run-64. Run-64 calcine simulant is a $\mathrm{Zr}$, Na blend as the result of blending $\mathrm{Zr}$ fuel reprocessing raffinates and incidental wastes containing sodium. Al calcine simulant is based on Al fuel reprocessing raffinates.

The simulant wastes utilized in this work have been developed based upon experience, which has been derived from many development projects. The complexity of the actual waste matrices has been reproduced as closely as possible in the simulant. The primary chemical components of the actual waste are present in the simulants, as well as many of the minor constituents. However, the simulated matrix does not account for some minor components. ${ }^{6}$

Each feed solution was filtered through a 0.45 micron filter prior to use. Simulants were spiked with ${ }^{137} \mathrm{Cs}$ to approximately $100 \mathrm{~Bq} / \mathrm{mL}$ with a National Institute of Standards (NIST) ${ }^{137}$ Cs tracer. Compositions of dissolved Al and Run-64 calcine feed solutions are shown in Table 1. The composition of actual WM-183, WM-183 simulant and average simulant feed solutions are shown in Table 2.

Table 1. Dissolved Al and Run 64 pilot-plant calcine feed compositions.

\begin{tabular}{lll}
\hline Component & Al Simulant & Run-64 Simulant \\
\hline Acid (M) & 1.5 & 1.18 \\
Al $(M)$ & 1.00 & 0.987 \\
Total Cs $(M)$ & $1.15 E-4$ & $7.90 \mathrm{E}-6$ \\
$\mathrm{Na}(\mathrm{M})$ & 0.043 & 0.090 \\
$\mathrm{Sr}(\mathrm{M})$ & $5.23 \mathrm{E}-4$ & $9.76 \mathrm{E}-4$ \\
$\mathrm{~K}(\mathrm{M})$ & 0.001 & 0.012 \\
$\mathrm{~B}(\mathrm{M})$ & 0.0125 & 0.0046 \\
$\mathrm{Ca}(\mathrm{M})$ & $\mathrm{ND}$ & 0.501 \\
$\mathrm{Fe}(\mathrm{M})$ & 0.0016 & 0.0066 \\
$\mathrm{Zr}(\mathrm{M})$ & $\mathrm{ND}$ & 0.121 \\
$\mathrm{NO} \mathrm{O}_{3}^{-}(\mathrm{M})$ & 4.83 & -3.0 \\
$\mathrm{~F}^{-}(\mathrm{M})$ & $\mathrm{ND}$ & 0.73 \\
${ }_{137} \mathrm{Cs}(\mathrm{Bg} / \mathrm{mL})$ & 169.0 & 161.0 \\
\hline $\mathrm{ND}=\mathrm{no} \mathrm{data}$ & &
\end{tabular}


Table 2. Actual tank WM-183 waste, WM-183 simulant and average tank waste simulant compositions.

\begin{tabular}{|c|c|c|c|}
\hline Component & $\begin{array}{l}\text { Actual } \\
\text { WM-183 }\end{array}$ & $\begin{array}{l}\text { WM-183 } \\
\text { Simulant }\end{array}$ & $\begin{array}{l}\text { Average Tank } \\
\text { Waste Simulate }\end{array}$ \\
\hline$\overline{\text { Acid }(M)}$ & 1.77 & 1.70 & 1.31 \\
\hline $\mathrm{Al}(\mathrm{M})$ & 0.64 & 0.62 & 0.59 \\
\hline$B(M)$ & 0.013 & 0.013 & 0.015 \\
\hline $\mathrm{Ca}(\mathrm{M})$ & 0.040 & 0.029 & 0.033 \\
\hline $\mathrm{Cl}(\mathrm{M})$ & 0.011 & 0.011 & 0.034 \\
\hline $\mathrm{Cr}(\mathrm{M})$ & 0.014 & 0.017 & 0.006 \\
\hline Total Cs (M) & 7.11E-5 & $9.8 \mathrm{E}-5$ & $7.14 E-5$ \\
\hline $\mathrm{Fe}(\mathrm{M})$ & 0.056 & 0.045 & 0.024 \\
\hline $\mathrm{Hg}(\mathrm{M})$ & 0.0023 & 0.0013 & 0.0018 \\
\hline$K(M)$ & 0.094 & 0.086 & 0.13 \\
\hline $\mathrm{Na}(\mathrm{M})$ & 0.68 & 0.69 & 1.04 \\
\hline $\mathrm{NO}_{3}(\mathrm{M})$ & 5.24 & 4.80 & 4.2 \\
\hline $\mathrm{Pb}(\mathrm{M})$ & 0.0012 & 0.0015 & $9.56 \mathrm{E}-4$ \\
\hline $\mathrm{SO}_{4}(\mathrm{M})$ & 0.066 & 0.066 & $8.85 \mathrm{E}-3$ \\
\hline $\operatorname{Sr}(M)$ & ND & $6.3 E-4$ & $5.57 \mathrm{E}-3$ \\
\hline $\mathrm{Zr}(\mathrm{M})$ & $4.2 E-4$ & 0.0065 & $5.78 E-4$ \\
\hline Alpha $(n \mathrm{Ci} / \mathrm{g})$ & 506 & N/A & N/A \\
\hline${ }^{241} \mathrm{Am}(\mathrm{nCi} / \mathrm{g})$ & 34.9 & N/A & N/A \\
\hline${ }^{238} \mathrm{Pu}(\mathrm{nCi} / \mathrm{g})$ & 333.8 & N/A & N/A \\
\hline${ }^{239} \mathrm{Pu}$ (nCi/g) & 123.3 & N/A & N/A \\
\hline$U(\mathrm{mg} / \mathrm{L})$ & 114 & N/A & N/A \\
\hline${ }^{237} \mathrm{~Np}(\mathrm{nCl} / \mathrm{g})$ & $<6.5$ & N/A & N/A \\
\hline${ }^{99} \mathrm{Tc}\left(\mathrm{Ci} / \mathrm{m}^{3}\right)$ & 0.036 & N/A & N/A \\
\hline${ }^{137} \mathrm{Cs}\left(\mathrm{Ci} / \mathrm{m}^{3}\right)$ & 219 & $\sim 100 \mathrm{~Bq} / \mathrm{mL}$ & $\sim 100 \mathrm{Bg} / \mathrm{mL}$ \\
\hline${ }^{90} \mathrm{Sr}\left(\mathrm{Ci} / \mathrm{m}^{3}\right)$ & 201 & N/A & N/A \\
\hline Density $(\mathrm{g} / \mathrm{mL})$ & 1.25 & ND & ND \\
\hline
\end{tabular}

$\overline{\mathrm{ND}}=$ no data, $\mathrm{N} / \mathrm{A}=$ not applicable 


\section{BATCH CONTACT EXPERIMENTS}

Two contacts per simulant were performed, each containing approximately 0.4 . and 0.1 grams of (Lot \#999096810002) IONSIV IE-911. Twenty-two mLs of each simulant were prepared and $0.110 \mathrm{mLs}$ of $5.4 \mu \mathrm{Ci} / 5 \mathrm{~mL}$ tracer was added to each solution. Ten $\mathrm{mLs}$ of simulant were used for each batch contact.

All contacts had a mixing time of 24 hours. Mixing was constant throughout the test using a mechanical rotary mixer, adjusted to approximately 15 rotations per minute. All contacts were performed in $20 \mathrm{~mL}$ borosilicate glass test tubes. Batch contact solutions were filtered through 0.45 micron syringe filters prior to ${ }^{137} \mathrm{Cs}$ analysis. All contacts were performed at room temperature $\left(21-25 \mathrm{C}^{\circ}\right)$. Batch contact experimental conditions are listed in Table 3.

Table 3. Batch contact experimental conditions.

\begin{tabular}{lcccc}
\hline Contact & $\begin{array}{c}\text { Contact } \\
\text { Time } \\
\text { (Hrs) }\end{array}$ & $\begin{array}{c}\text { Solution } \\
\text { Volume } \\
\text { (mLs) }\end{array}$ & $\begin{array}{c}\text { Sorbent } \\
\text { Weight } \\
\text { (g) }\end{array}$ & $\begin{array}{c}\text { Waste Type } \\
\text { (All Simulants) }\end{array}$ \\
\hline$\# 1$ & 24 & 10 & 0.40336 & WM-183 \\
$\# 2$ & 24 & 10 & 0.40168 & Al \\
$\# 3$ & 24 & 10 & 0.40050 & Run-64 \\
$\# 4$ & 24 & 10 & 0.10036 & WM-183 \\
$\# 5$ & 24 & 10 & 0.10359 & Al \\
$\# 6$ & 24 & 10 & 0.10161 & Run-64 \\
\hline
\end{tabular}




\section{BATCH DISTRIBUTION COEFFICIENT $\left(\mathbf{K}_{d}\right)$}

The batch distribution coefficient $\left(K_{d}\right)$ is an equilibrium measure of the overall ability of the solid phase ion exchange material to remove an ion from solution under the particular environmental conditions that exist during the contact. The batch distribution coefficient $K_{d}$ is an experimental way of determining the affinity of a sorbent material for a specific ion. $K_{d}$ can also be used as an indicator of the selectivity and affinity of an ion in the presence of a complex matrix of interfering ions. Larger $\mathrm{K}_{\mathrm{d}}$ values indicate a greater amount of ions are concentrated onto the sorbent material. ${ }^{7}$

To ensure accurate comparison of $K_{d}$ results, several factors need to be considered. Experimental conditions such as volume: mass ratio, temperature, solution composition, material pretreatment, etc can affect $K_{d}$ results. Distribution coefficient $\left(K_{d}\right)$ values were calculated according to the following formula:

$$
K_{d}=\frac{\left(C_{0}-C_{e}\right)}{C_{e}} * \frac{V}{M}
$$

Where:

$\mathrm{C}_{0}=$ initial concentration of the ion in solution before contacting sorbent.

$\mathrm{C}_{\mathrm{e}}=$ final equilibrium concentration of the ion in solution after contacting sorbent. $\mathrm{V}=\mathrm{mL}$ of solution. $M=$ grams of sorbent material contacted.

\section{COLUMN PREPARATION}

A consistent procedure was used to load each column. The top of the column was removed and the column was filled with deionized water prior to loading. A polyethylene frit was placed at the bottom prior to sorbent addition to prevent particle loss. A piece of Nalgene tubing was then attached to the top of the column and a funnel or large syringe was secured to the other end of the tubing which was also filled with deionized water. A precisely measured dry sorbent weight was slurried into the funnel or syringe, and allowed to gravity-settle into the column. The column was gently tapped while the particles collected into a uniform column bed. Quantitative sorbent transfer was verified during each loading by inspecting the weighing dish, funnel or syringe to ensure all particles were transferred to, and remained in, the column. After sorbent preparation was completed, several $\mathrm{mLs}$ of deionized were processed through the column to flush unwanted fines. ${ }^{1}$ It should be noted that (Lot \#999096810002) IONSIV IE-911, with a mean size of $200 \mu \mathrm{m}$, was used in these experiments. Particles were not screened or fractionated. In addition, the sorbent was not pretreated to equilibrate it to the $\mathrm{pH}$ of the feed solution. 


\section{COLUMN EXPERIMENTS}

Two different sized columns were used for these experiments: $1 \mathrm{~cm}^{3}$ and $1.5 \mathrm{~cm}^{3}$ respectively. IONSIV IE-911 was tested using a $1 \mathrm{~cm}^{3}$ column with actual WM-183 tank waste and average tank waste simulant. The column was fabricated from stainless steel and was designed for downward flow through the column. The bed portion of the column was $35 \mathrm{~mm}$ high and $6.2 \mathrm{~mm}$ diameter.

IONSIV IE-911 was also tested using a $1.5 \mathrm{~cm}^{3}$ column with dissolved Al and Run-64 calcine simulants. The $1.5 \mathrm{~cm}^{3}$ column was fabricated from stainless steel and incorporated a Plexiglas bed section. The Plexiglas bed section allowed for visual inspection of bed material during operation. The bed section of the column was $21 \mathrm{~mm}$ high and $9.5 \mathrm{~mm}$ diameter. The column was designed for upward or downward flow. Downward flow was used for all experiments involving the $1.5 \mathrm{~cm}^{3}$ column. The process schematic of the assembled ion-exchange process is shown in Figure 1.

Figure 2 (Photo) displays the ion-exchange set-up installed at the Remote Analytical Laboratory (RAL). The column shown in Figure 2 is configured for up flow, however, all tests with IONSIV IE-911 were performed with downflow through the column.

An FMI valveless metering pump (Model QVG-50) was used to provide feed solution to the columns. Flow rates were controlled by controlling the pump with a tenturn potentiometer FMI Stroke Rate Controller (Model V100). The appropriate tubing and fittings were used to connect equipment. Properties of the IONSIV IE-911 column experiments are listed in Table 4.

Table 4. Properties of the IONSIV IE-911 column experiments.

\begin{tabular}{lllll}
\hline Property & Run-64 & Al Simulant & $\begin{array}{l}\text { Tank Waste } \\
\text { Simulant }\end{array}$ & $\begin{array}{l}\text { Actual Tank } \\
\text { WM-183 Waste }\end{array}$ \\
\hline Sorbent Wt. & $1.49 \mathrm{~g}$ & $1.50 \mathrm{~g}$ & $1.05 \mathrm{~g}$ & $1.02 \mathrm{~g}$ \\
Feed Flowrate & $9 \mathrm{~mL} / \mathrm{hr}$ & $9 \mathrm{~mL} / \mathrm{hr}$ & $5.7 \mathrm{~mL} / \mathrm{hr}$ & $5.7 \mathrm{~mL} / \mathrm{hr}$ \\
Superficial Vel. & $11.5 \mathrm{~cm} / \mathrm{hr}$ & $11.5 \mathrm{~cm} / \mathrm{hr}$ & $18.9 \mathrm{~cm} / \mathrm{hr}$ & $18.9 \mathrm{~cm} / \mathrm{hr}$ \\
BV/hr & 6.0 & 6.0 & 5.4 & 5.5 \\
Vol. Processed & $1770 \mathrm{mLs}$ & $1567 \mathrm{mLs}$ & $800 \mathrm{mLs}$ & $800 \mathrm{mLs}$ \\
Bed Volumes & & & & \\
Processed & 1187 & 1044 & 761 & 784 \\
\hline
\end{tabular}




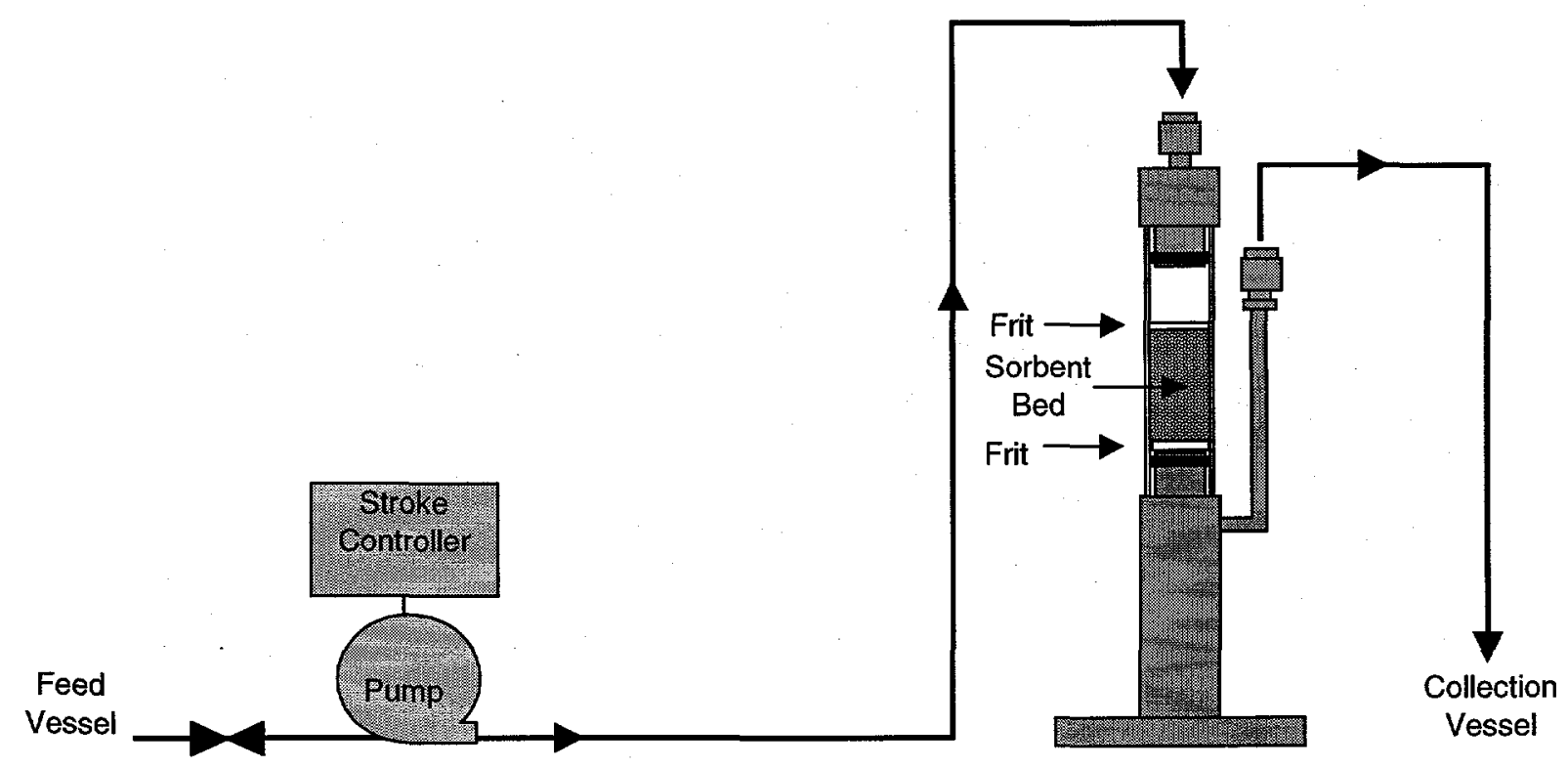

Figure 1. Process schematic of assembled ion-exchange process. 


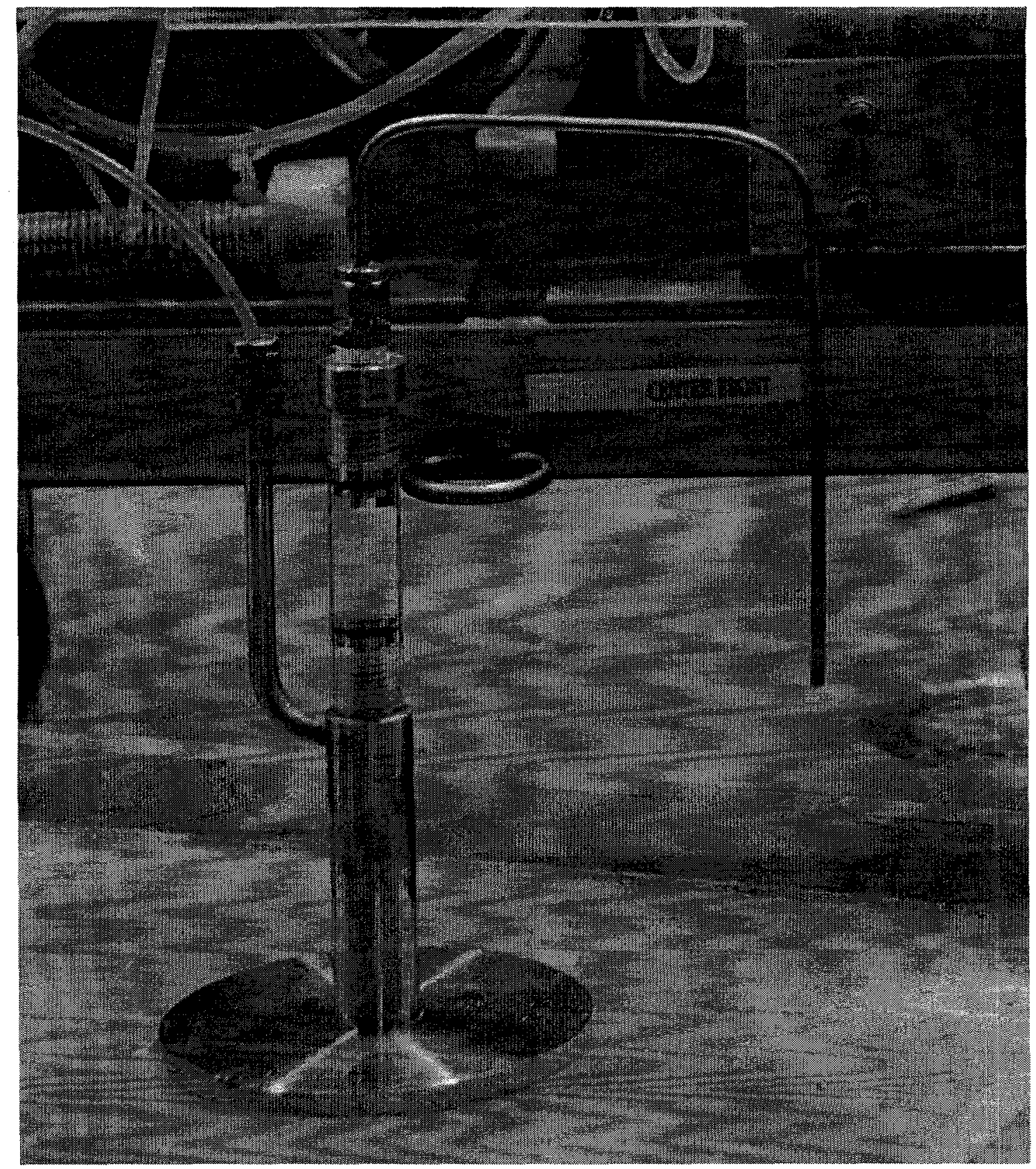

Figure 2. The ion-exchange set-up installed at the Remote Analytical Laboratory (RAL). 


\section{SAMPLING AND ANALYSIS}

Column effluents from tests using dissolved $\mathrm{Al}$ and Run-64 calcine simulants were collected via an Eldex ${ }^{\odot}$ fraction collector accompanied by a U-136 $(9 \mathrm{~mL})$ collection rack, containing 136 collection tubes. Fractions were collected in 45-minute intervals providing $6.75 \mathrm{mLs}$ per collection tube, two hundred and ninety six (296) samples in all. Sample fractions were collected in factors of 10 . Collection tubes directly proceeding and directly following the $10^{\text {th }}$ tube were collected and combined with the amount of the $10^{\text {th }}$ tube ( $20.25 \mathrm{mLs}$ total) to provide adequate aliquots for analysis. One and $15 \mathrm{~mL}$ aliquots were collected and dispensed into $15-\mathrm{mL}$ glass scintillation vials and $30 \mathrm{~mL}$ polypropylene bottles, respectively. After the aliquots were collected, the remaining volume was recorded. The recorded volume was used to calculate the cumulative volume through the column. Flow rate was recorded by measuring the volume of the collected sample and the time used to collect the sample.

Column effluents from the test using actual WM-183 SBW were collected in a glass beaker approximately every 3 to 5 hours. The effluent volume of each sample fraction was measured by pouring the sample into a clean graduated cylinder. The sample fraction was then poured into an unused polyethylene bottle, the beaker and graduated cylinder were thoroughly rinsed with deionized water and inverted to dry. Two beakers were used during actual waste testing, one of which was drying while the other was being used to collect effluent fractions. Each sample fraction required dilution with 3 $\%$ nitric acid prior to removing a sample aliquot from the shielded (hot) cell for ${ }^{137} \mathrm{Cs}$ analysis to reduce the radioactivity in the sample to safe handling limits. Each sample had to be diluted to less than 100 millirem total dose before it could be transferred from the hot cell. Typically, a $0.1 \mathrm{~mL}$ to $20.1 \mathrm{~mL}$ dilution was used. A $1 \mathrm{~mL}$ aliquot of the diluted fraction was taken with a $1 \mathrm{~mL}$ Eppindorf pipettor and dispensed into a 5 gram glass vial for ${ }^{137} \mathrm{Cs}$ analysis. ${ }^{1}$

Column effluents from tests using the average simulant were collected in polyethylene bottles at specified time intervals. Sampling times changed during testing because continuous testing was attempted; therefore, the operation was not always attended. Those samples that were collected in the morning, after the experiment had been operating all night, were larger than those samples collected during the day and evening. Sampling frequency was also decreased during weekends, and the columns had to be shut down for the weekend occasionally. ${ }^{1}$

${ }^{137}$ Cs activities, for all experiments, were determined by Gamma Spectrometry using a high efficiency germanium detector. $\mathrm{Sr}, \mathrm{Al}$ and $\mathrm{Ca}$ were analyzed using Inductively Coupled Plasma Atomic Emission Spectrophotometry (ICP-AES). Na, Kand total Cs were analyzed separately by Atomic Absorption Spectrophotometry (AAS). 


\section{RESULTS AND DISCUSSION}

\section{BATCH CONTACT EXPERIMENTS}

Results of batch contact $\left(K_{d}\right)$ experiments are shown in Table 5. Batch contact experiments using simulated $W M-183$, with volume to mass ratios of approximately 25 and 100 displayed $K_{d}$ values of 1225.43 and 1119.92 , respectively. Batch contact experiments using dissolved Al pilot-plant calcine, with a volume to mass ratios of approximately 25 and 100 , displayed $K_{d}$ values of 1623.01 and 1487.44 , respectively. Batch contact experiments using dissolved Run-64 pilot-plant calcine with volume to mass ratios of approximately 25 and 100 , displayed $K_{d}$ values of 4926.10 and 3694.34 , respectively.

Table 5. Batch contact experimental conditions and results.

\begin{tabular}{lccccc}
\hline Contact & $\begin{array}{c}\text { Contact } \\
\text { Time } \\
\text { (hrs) }\end{array}$ & $\begin{array}{c}\text { Solution } \\
\text { Volume } \\
\text { (mLs) }\end{array}$ & $\begin{array}{c}\text { Sorbent } \\
\text { Weight } \\
\text { (g) }\end{array}$ & Waste Type & $\mathrm{K}_{\mathrm{d}}$ \\
\hline$\# 1$ & 24 & 10 & 0.40336 & WM-183 & 1225.43 \\
$\# 2$ & 24 & 10 & 0.40168 & $\mathrm{Al}$ & 1623.01 \\
$\# 3$ & 24 & 10 & 0.40050 & Run-64 & 4926.10 \\
$\# 4$ & 24 & 10 & 0.10036 & WM-183 & 1119.92 \\
$\# 5$ & 24 & 10 & 0.10359 & Al & 1487.44 \\
$\# 6$ & 24 & 10 & 0.10161 & Run-64 & 3694.34 \\
\hline
\end{tabular}

\section{COLUMN TESTS}

\section{Al Simulant}

Figure 3 displays the ${ }^{137} \mathrm{Cs}, \mathrm{Al}, \mathrm{Na}$ and $\mathrm{Sr}$ breakthrough curves for dissolved, aluminum calcine simulant. The percent breakthrough $\left(\mathrm{C} / \mathrm{CO}^{*} 100\right)$ is plotted against the bed volumes of solutions passed through the column. Initial ${ }^{137} \mathrm{Cs}$ breakthrough was observed at approximately 37.5 bed volumes. Fifty Percent ${ }^{137} \mathrm{Cs}$ breakthrough occurred at 756 bed volumes. Al, $\mathrm{Na}$ and $\mathrm{Sr}$ are not sorbed on the IONSIV IE-911, as evidenced by $\sim 100 \%$ breakthrough for the duration of the test. 


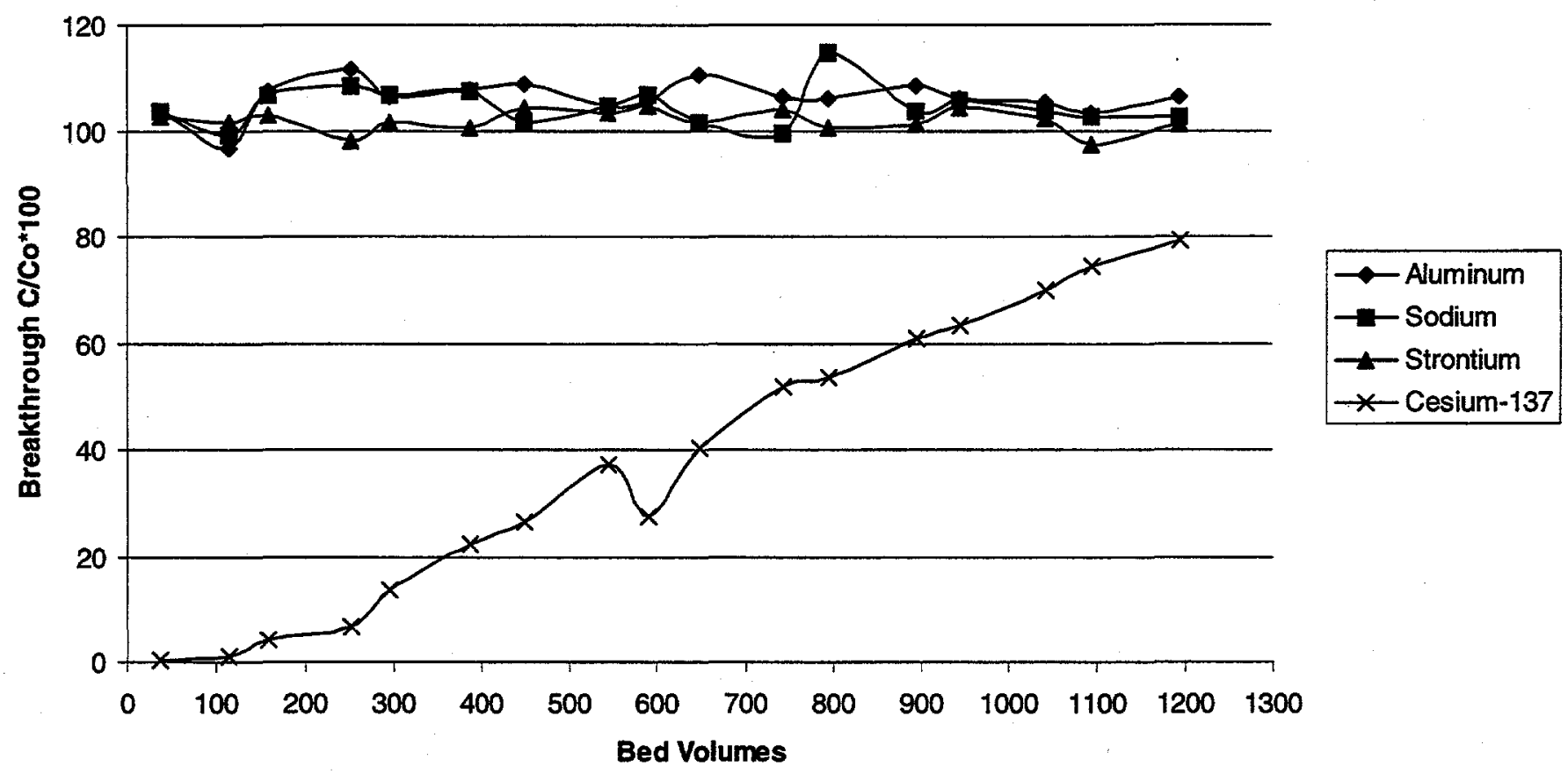

Figure 3. Cesium-137, Al, $\mathrm{Na}$ and $\mathrm{Sr}$ breakthrough curves for dissolved Al calcine simulant.

The slight decrease in ${ }^{137} \mathrm{Cs}$ breakthrough displayed at approximately 600 bed volumes was the result of a temporary (12 hour) shut down. During the shut down, equilibrium within the column was approached.

\section{RUN-64 Simulant}

Figure 4 displays the ${ }^{137} \mathrm{Cs}, \mathrm{Ca}, \mathrm{Na}, \mathrm{Sr}$ and $\mathrm{K}$ breakthrough curves for dissolved, Run-64 pilot-plant calcine. The percent breakthrough $\left(\mathrm{C} / \mathrm{Co}^{*} 100\right)$ is plotted against the bed volumes of solutions passed through the column. Initial ${ }^{137} \mathrm{Cs}$ breakthrough was observed at approximately 53 bed volumes. Fifty Percent ${ }^{137} \mathrm{Cs}$ breakthrough was never achieved throughout the test. $\mathrm{Ca}, \mathrm{Na}, \mathrm{Sr}$ and $\mathrm{K}$ are not sorbed on the IONSIV IE-911, as evidenced by $100 \%$ breakthrough for the duration of the test. Relatively high concentrations of $\mathrm{Ca}, \mathrm{Na}, \mathrm{Sr}$ and $\mathrm{K}$ observed in initial samples could possibly be the result of evaporation of the feed solution, which in turn increased initial concentrations. 


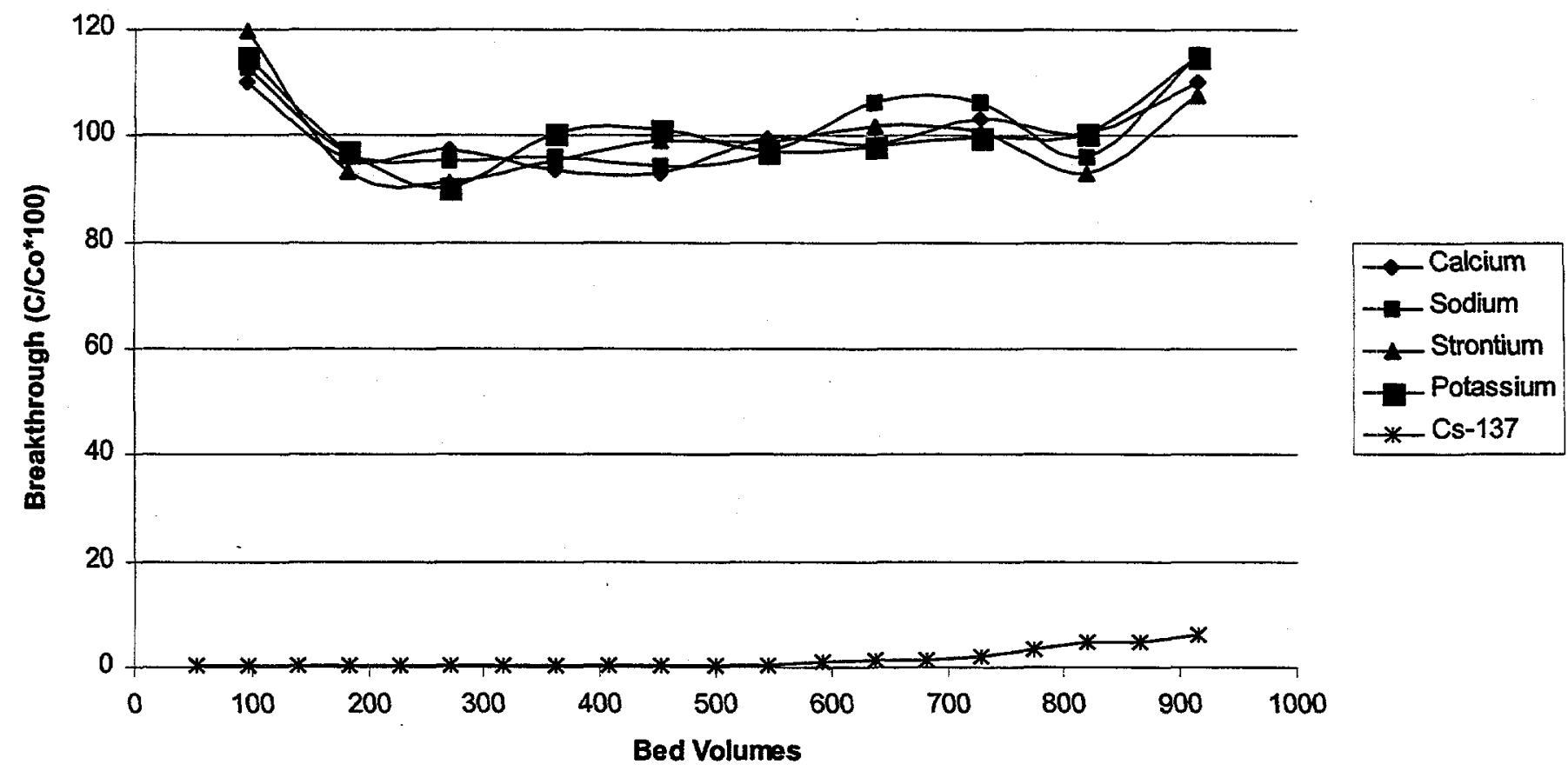

Figure 4. Cesium-137, $\mathrm{Ca}, \mathrm{Na}, \mathrm{Sr}$ and $\mathrm{K}$ breakthrough curves for dissolved Run-64 pilot-plant, calcine simulant.

\section{ACTUAL SBW-183 TANK WASTE AND AVERAGE TANK WASTE SIMULANT}

Cesium breakthrough curves obtained from the actual WM-183 and average tank waste simulant are shown in Figure 5 . Fifty percent breakthrough for Cs occurred at approximately $700 \mathrm{BV}(700 \mathrm{mLs})$ for both wastes.

It is important to note that $50 \%$ breakthrough was achieved much sooner, compared to the Run-64 $(1.0 \mathrm{ug} / \mathrm{mL})$, due to concentrations of $10-13 \mathrm{ug} / \mathrm{mL}$ stable Cs within the feed solution. 


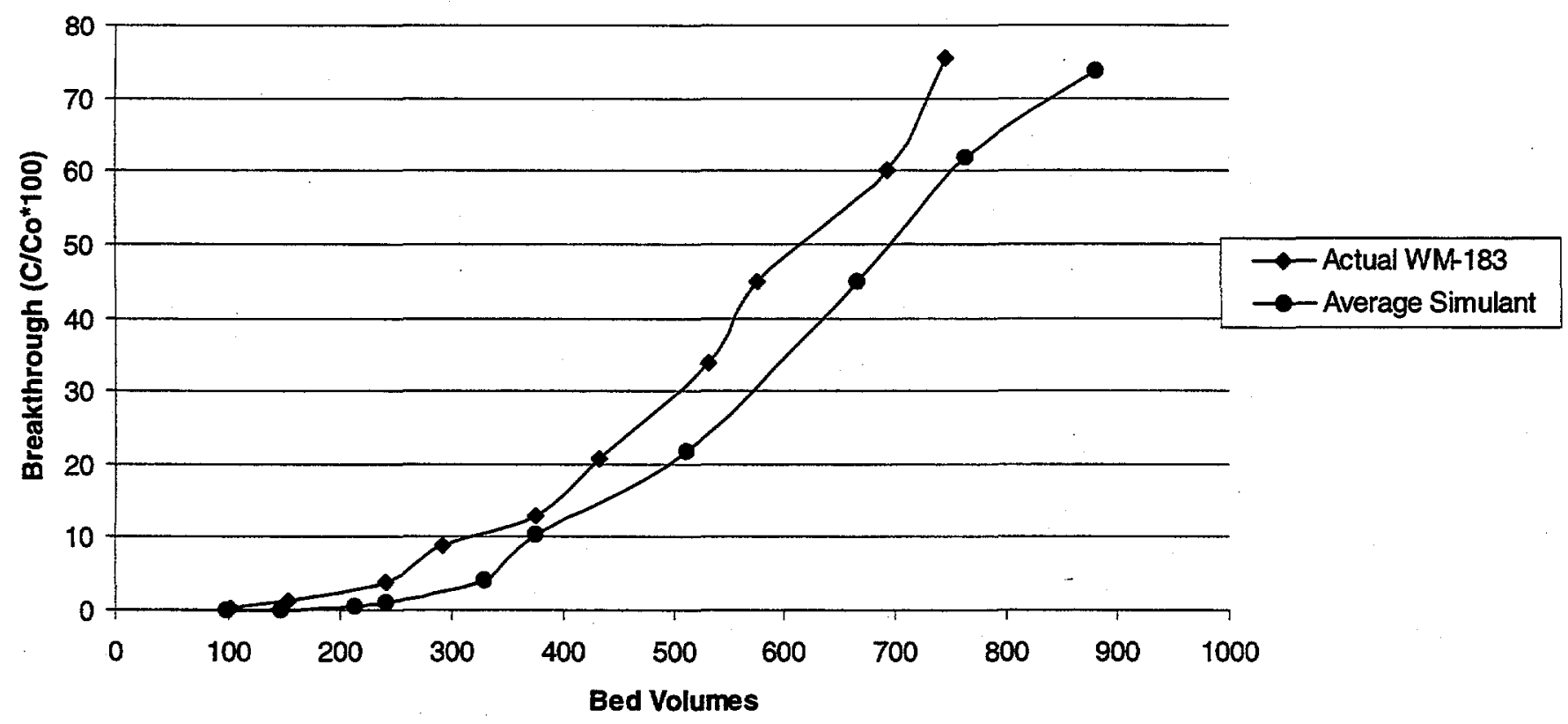

Figure 5. Cesium-137 breakthrough curves for actual WM-183 tank waste and average tank waste simulant.

\section{DYNAMIC CAPACITY}

Data plots of throughput volume (liters) against column effluent Cs concentration ( $\mathrm{mmole} / \mathrm{L}$ ) were generated using experimental column breakthrough data presented previously. A second order kinetic equation was fit to each of these data sets to obtain a relationship for $C s$ effluent concentration as a function of throughput volume. This equation for Cs concentration was then substituted into the following relationship for dynamic capacity (DC):

$$
\mathrm{DC}=\frac{\int_{0}^{v}\left(C_{0}-C\right) d v}{M}
$$

Where:

$$
\begin{aligned}
& v=\text { volume at a specified breakthrough, Liters } \\
& C o=\text { initial Cs concentration, mmole/L } \\
& C=\text { Cs concentration in the column effluent, mmole/L } \\
& M=\text { mass of sorbent, grams (dry weight) }
\end{aligned}
$$


Dynamic capacity estimates were obtained by evaluating the integral numerically with upper limit volume values corresponding to approximately $50 \%$ and $100 \%$ Cs breakthrough. Dynamic capacities for the small-scale column experiments using actual tank WM-183 waste, tank waste simulant and dissolved Al and Run-64 pilot plant calcine simulants are shown in Table 6.

Table 6. Dynamic capacities for small-scale column experiments.

\begin{tabular}{lll}
\hline Feed Solution & Dynamic Capacity at & $\begin{array}{l}\text { Dynamic Capacity at } \\
100 \% \text { breakthrough }\end{array}$ \\
\hline Dissolved Al Calcine Simulant & $50 \%$ breakthrough & $7.55 \mathrm{E}-02 \mathrm{mmole} / \mathrm{g}$ \\
Dissolved Run-64 Calcine Simulant & $8.79 \mathrm{E}-03 \mathrm{mmole} / \mathrm{g}^{1}$ & $1.08 \mathrm{E}-02 \mathrm{mmole} / \mathrm{g}$ \\
Actual Tank WM-183 Waste & $3.76 \mathrm{E}-02 \mathrm{mmole} / \mathrm{g}$ & $4.31 \mathrm{E}-02 \mathrm{mmole} / \mathrm{g}$ \\
Average Tank Waste Simulant & $4.06 \mathrm{E}-02 \mathrm{mmole} / \mathrm{g}$ & $5.02 \mathrm{E}-02 \mathrm{mmole} / \mathrm{g}$ \\
\hline
\end{tabular}
'estimated from breakthrough curve 


\section{CONCLUSIONS}

- Batch contact experiments using simulated INEEL wastes indicate that IONSIV IE911 has a high affinity for cesium at nitric acid concentrations up to $1.7 \mathrm{M}$.

- Column test data indicate that cesium is selectively sorbed over $\mathrm{Al}, \mathrm{Na}, \mathrm{Sr}, \mathrm{Ca}$ and K.

- The slope of the breakthrough curves observed in this work were relatively low. The cause for this is unknown, but may be that at $6 \mathrm{BV} / \mathrm{hr}$, the sorbent was limited by ion diffusion into the sorbent particle. No testing to establish sorption kinetics was performed as part of this study, but is currently in progress. 


\section{REFERENCES}

1. Todd, T. A., Brewer, K. N., Wood, D. J., Tullock, P. A., Olson, L. G., Olson, A. L., "Evaluation and Testing of Inorganic Ion Exchange Sorbents for the Removal of ${ }^{137}$ Cs from Idaho Chemical Processing Plant Acidic Tank Waste," Separation Science and Technology, in press.

2. Miller, J. E., Brown, N. E., "Development and Properties of Crystalline Silicotitanate (CST) Ion Exchange for Radioactive Waste Applications", SAND97-0771 / UC-721, UC-510, April 1997.

3. Braun, R., Dangieri, T. J., Fennelly, D. J., Sherman, J. D., Schwerin, W. C., Willis, R. R., Brown, N. E., Miller, J. E., Anthony, R. G., Philip, C. V., Bray, L. A., Brown, G. N., Lee, D. D., Borek, T. T., Connors, W. J., "Ion Exchange Performance of Commercial Crystalline Silicotitanates for Cesium Removal", Waste Management 96, Tucson, Arizona.

4. Thompson, M. C., "Pretreatment/Radionuclide Separations of Cs/Tc from Supernates", WSRC-MS-98-00601.

5. Lee, D. D., Travis, J. R., Gibson, M. R., "Hot Demonstration of Proposed Commercial Cesium Removal Technology", ORNL/TM-13169, December 1997.

6. Wood, D. J., Law, J. D., Garn, T. G., Tillotson, R. D., Tullock, P. A. and Todd, T. A., "Development of the SREX Process for the Treatment of ICPP Liquid Wastes", INEEL/EXT-97-00831, October 1997.

7. Brown, G. N., Bray, L. A., Carlson, C. D., Carson, K. J., DesChane, J. R., Elovich, R. J., Hoopes, F. V., Kurath, D. E., Nenninger, L. L., Tanaka, P. K., "Comparison of Organic and Inorganic Ion Exchangers for Removal of Cesium and Strontium from Simulated and Actual Hanford 241-AW-101 DSSF Tank Waste", PNL-10920/UC2030, January 1996. 
EXPERIMENTAL DATA 


\begin{tabular}{|c|c|}
\hline 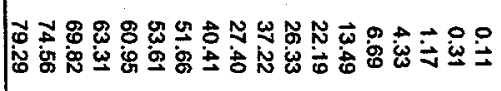 & 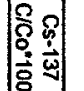 \\
\hline 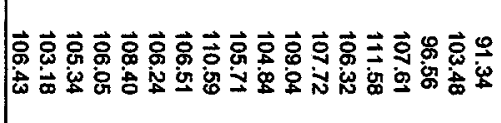 & \\
\hline 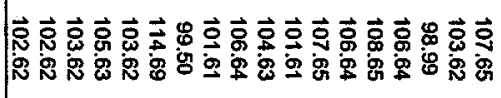 & 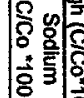 \\
\hline 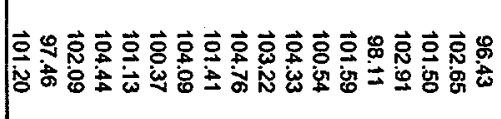 & 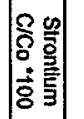 \\
\hline
\end{tabular}

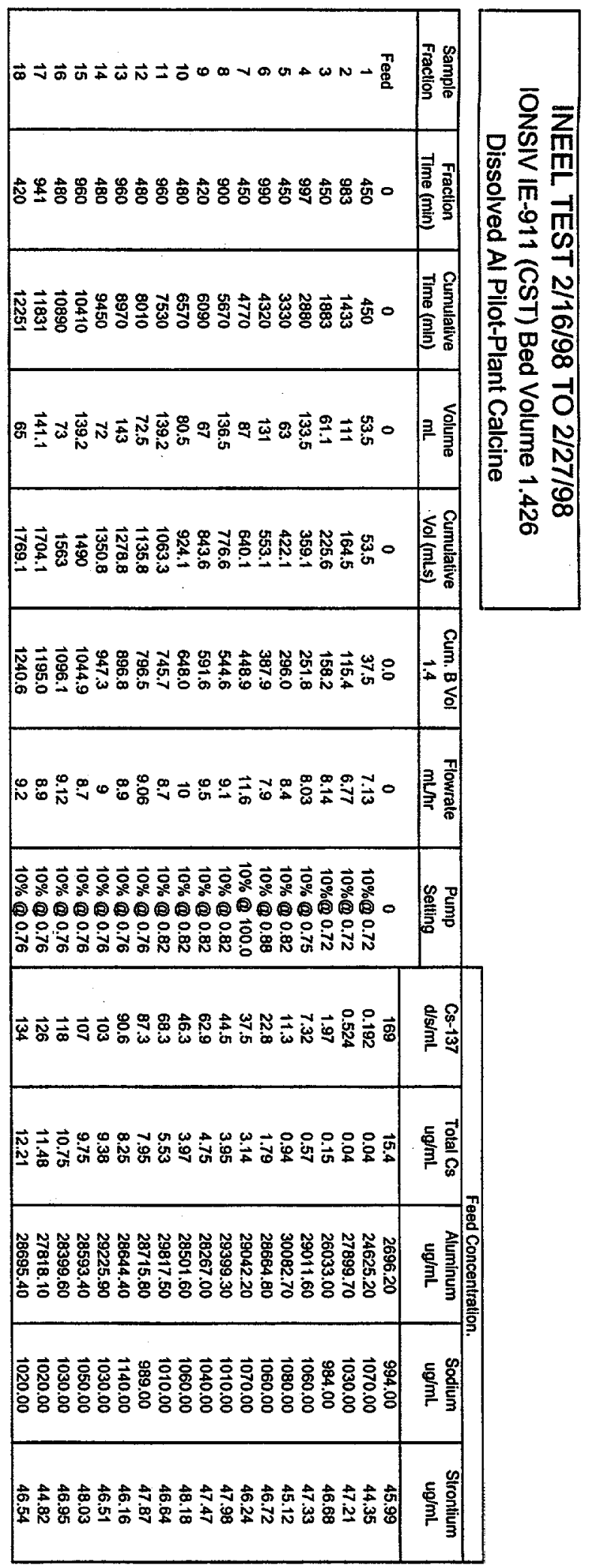




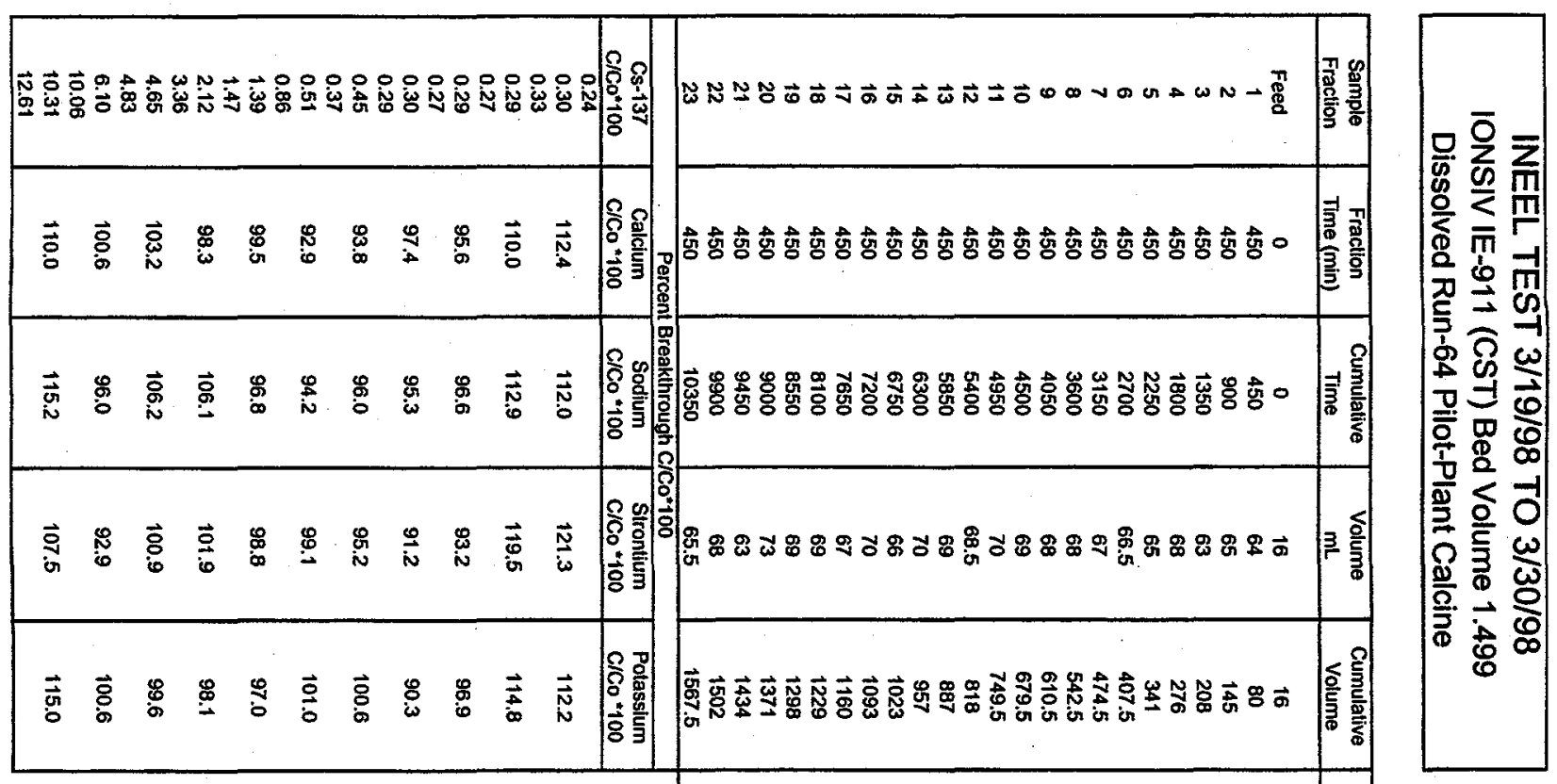

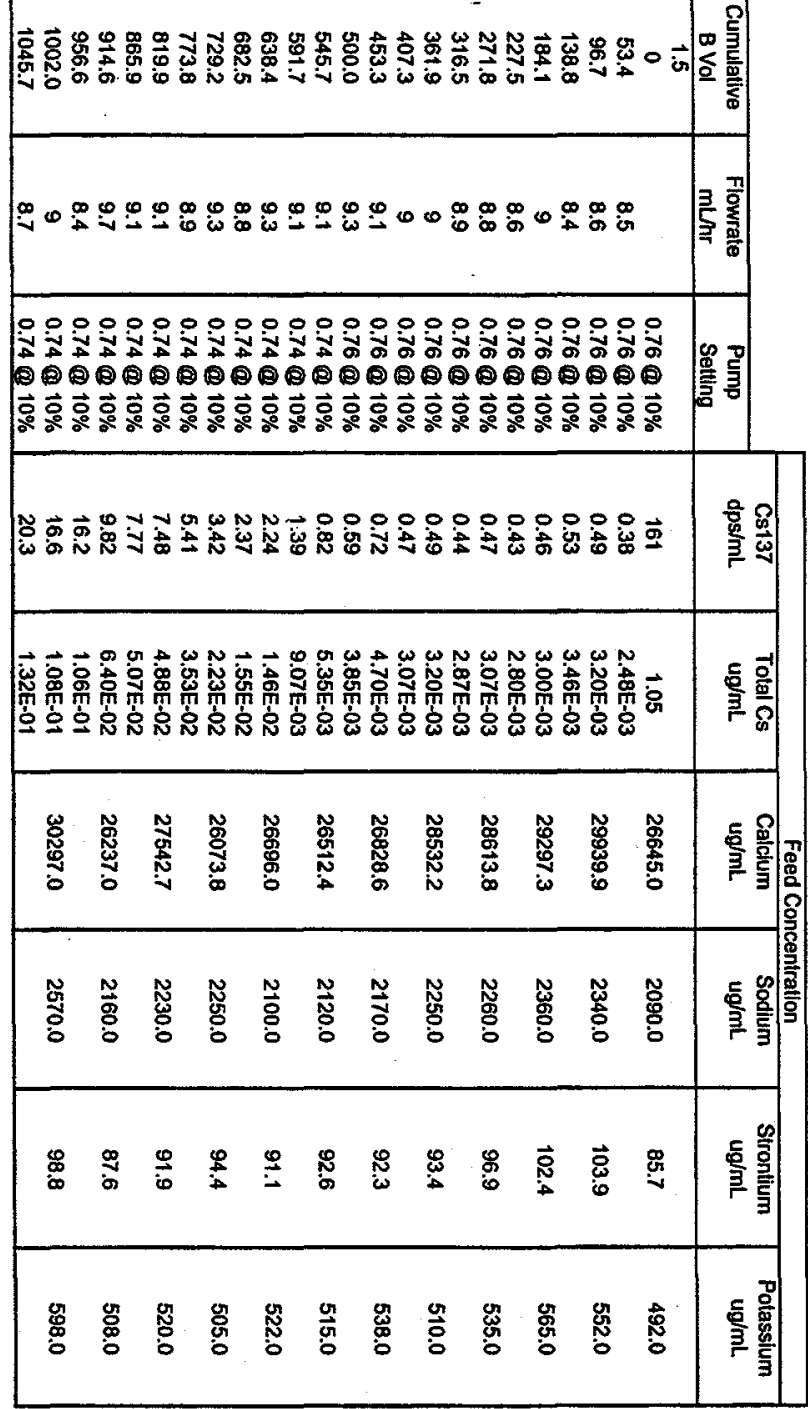



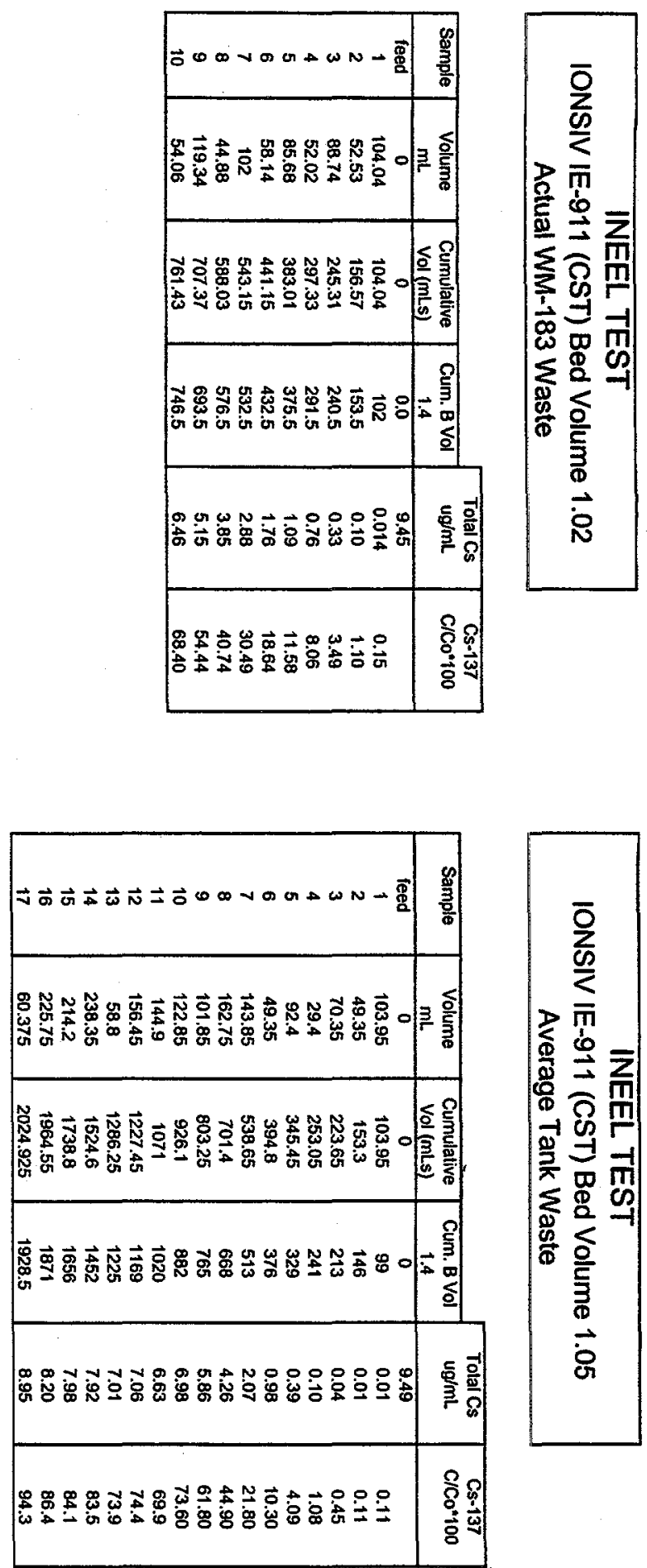